\title{
ЕОЗИНОФІЛЬНИЙ ГАСТРИТ У ДІТЕЙ: ОСОБЛИВОСТІ МОРФОГЕНЕЗУ
}

\author{
Боброва В. I. \\ доктор медичних наук, професор кафедри педіатрії №1 \\ Національний медичний університет імені О.О. Богомольия, м. Київ, Україна
}

DOI: https://doi.org/10.31435/rsglobal_conf/30112020/7270

\begin{abstract}
The article presents characteristics of morphological and immunohistochemical changes of the gastric mucosa in children with eosinophilic gastritis. The course of eosinophilic gastritis in children is characterized by an imbalance of cell regeneration processes.

It was found that most children were diagnosed with hemorrhage, microthrombosis, stromal fibrosis, proliferation of fibroblasts and collagen fibers. In a process of immunohistochemical examination of gastric biopsies, most children with eosinophilic gastritis revealed uneven expression of the VEGFR 1 receptor in gastric endothelial cells. Type IV collagen expression was determined in the individual fragmented foci in the basement membranes of the superficial epithelium and single glandular structures. Advanced expression of TGFR $\beta$ positive cellular elements was diagnosed only in patients with severe gastric mucosal fibrosis. The data that has been collected indicates that the course of eosinophilic gastritis is accompanied by microcirculation disorders and stromal-epithelial change of the gastric mucosa.
\end{abstract}

Keywords: children, eosinophilic gastritis, microcirculation of the gastric mucosa, fibrosis, fibrous remodeling.

Вступ. Еозинофільні захворювання шлунково-кишкового тракту (ШКТ) - хронічні імунопатологічні захворювання, які протікають 3 переважно еозинофільним запаленням слизової оболонки (СО) різних відділів ШКТ. Недостатньо вивчена патологія, тенденція до зростання якої спостерігається в останні роки $[4,12]$. Діагностика еозинофільних захворювань ШКТ викликає труднощі у зв’язку 3 варіабельністю їх клінічних проявів. Морфологічне дослідження біоптатів СО ШКТ є стандарт діагностики еозинофільних захворювань ШКТ і безумовними ознаками еозинофільного запалення $\epsilon$ наявність скупчення еозинофілів в поєднанні з фіброзом [2, 5].

Основні патогенетичні механізми, що приводять до виникнення еозинофільного ураження ШКТ, невідомі. Експерти припускають, що за рахунок вивільнення таких цитокінів, як IL-2, IL-4, IL-5, IL-10, IL-12, IL-13, IL-16, IL-18, трансформуючого фактору росту TGF $\beta$, хемокінів (еотоксин), ліпідних медіаторів (фактор активації тромбоцитів і лейкотрієнів C4), еозинофіли можуть опосередковано підтримувати прозапальну реакцію в СО ШКТ $[11,14]$. На теперішній час доведена провідна роль TGF $\beta$ в посиленні фіброзного ремоделювання CO, експресія якого посилена при еозинофільних захворюваннях ШКТ як у дітей, так і у дорослих. TGF $\beta$ відноситься до групи цитокінів, які стимулюють регенераторні процеси, ріст сполучної тканини, утворення фібронектину $[1,6]$. В процесі фіброзного ремоделювання активну участь приймають і еозинофіли. При активації еозинофіли продукують еозинофільну пероксидазу, еозинофільну колагеназу, хемокіни 2-го типу, які підвищують проникність судин, посилюють проліферацію фібробластів i сприяють формуванню фіброзного ремоделювання. Порушення кровопостачання СО ШКТ призводить до зміни структури, цілісності і функції травної системи. На теперішній час багато уваги приділяється біорегулятору ангіогенезу - васкулярному фактору росту ендотелію судин (VEGF). Первинним тригером, що активує експресію судинних факторів росту та появу рецепторів до VEGF, $є$ гіпоксія. Регенерація CO відбувається під впливом VEGF та ангіопоетинів, які відіграють важливу роль у відновленні сполучної тканини і мікросудин при пошкодженнях СО ШКТ [2, 10]

У сучасній класифікації еозинофільні захворювання ШКТ розрізняють за основним залученим органом [7, 8, 9] і виділяють: еозинофільний езофагіт; еозинофільний гастрит; еозинофільний гастроентерит; еозинофільний коліт. Перші клінічні прояви гастроінтестинальної харчової алергії часто перебігають під маскою функціональних порушень у вигляді колік, зригувань, метеоризму, діареї. При недостатній увазі до гастроінтестинальних проявів харчової алергії в ранньому віці, у дітей формуються різні форми еозинофільних запальних захворювань ШКТ [3, 13]. 
Еозинофільний гастрит - це хронічне імунопатологічне захворювання з еозинофільною інфільтрацією слизової оболонки шлунка (СОШ). За даними літератури поширеність еозинофільного гастриту становить 3-8 на 100 тисяч жителів [4]. Сучасні уявлення про формування та розвиток еозинофільного гастриту базуються на узагальнюючій концепції еозинофільного запалення і не мають чітких клінічних та морфологічних критеріїв діагностики. Наведені дані $є$ суттєвим аргументом на користь вивчення феномену еозинофільного запалення і фіброзного ремоделювання СОШ у дітей при еозинофільному гастриті.

Мета: вивчити особливості морфологічних та імуногістохімічних змін СОШ при еозинофільному гастриті у дітей.

Методи дослідження. Для верифікації діагнозу всім дітям проводили фіброезофагогастродуоденоскопічне дослідження (ФЕГДС) з прицільною біопсією СО тіла, антрального відділу шлунка для подальшого морфологічного та імуногістохімічного дослідження. Для оцінки гістологічних змін СОШ тканинні зрізи фарбували гематоксиліном та еозином і пікрофуксином по Ван-Гізон. Результати дослідження трактували відповідно Кіотського консенсусу, 2015 року.

Для імуногістохімічного дослідження зрізи завтовшки 4-6 мкм наносили на адгезивні предметні скельця Super Frost Plus і використовували непрямий стрептавидін-пероксидазний метод забарвлення. Апоптоз визначали 3 мишачими моноклональними антитілами до антиапоптозного білка $\mathrm{Bcl}-2$ (Clone 124, DAKO, Данія) і проапоптотозного протеїну Вах (Clone 2D2, DAKO, Данія). Для визначення проліферації використовували ядерний антиген проліферуючих клітин (Proliferating Cell Nuclear Antigen - PCNA) (Clone: PC10, DAKO, Данія). Колаген типували з моноклональними антитілами до Collagen Typ IV (Clone COL - 94, DAKO, Данія). Трансформуючий фактор росту TGF $\beta$ типували з поліклональними антитілами до TGF $\beta$ (DAKO, Данія). Фактор росту клітинних структур i судин VEGFR1 типували 3 моноклональними антитілами до VEGFR 1(Flt - 11, DAKO, Данія).

Інтерпретацію результатів імуногістохімічного забарвлення проводили відповідно до типу реакції. При використанні моноклональних антитіл до антиапоптозного білку $\mathrm{Bcl}-2$, проапоптозного протеїну Вах оцінювали кольорові реакції в цитоплазмі клітин, при використанні ядерного антигену проліферуючих клітин враховували ядерне забарвлення. Облік позитивних реакцій проводили за кількістю відредагованих клітин - виражали у відсотках до загальної кількості клітин на площі гістологічного препарату. При інтерпретації імунозабарвлення з використанням моноклональних антитіл до Collagen TypIV, VEGFR - 1 (Flt - 11) та поліклональних антитіл до TGF $\beta$, розповсюдженість та інтенсивність реакції оцінювали напівкількісним методом в балах, від 0 до 3 балів:

а) розповсюдженість:

1) 0 - немає забарвлення;

2) 1 - менше $10 \%$ позитивно забарвлених клітин;

3) 2 - більше $10 \%$ і менше $50 \%$ позитивно забарвлених клітин;

4) 3 - гомогенне забарвлення більше 50\% клітин;

б) інтенсивність реакції:

1) 0 - немає видимого забарвлення;

2) 1 - слабке забарвлення;

3) 2 - помірне забарвлення;

4) 3 - виразне забарвлення.

Статистичну обробку результатів проводили за загальноприйнятими методами варіаційної статистики.

Результати дослідження. Під нашим спостереженням було 112 дітей віком від 8 до 16 років 3 веріфікованим діагнозом хронічний гастрит в періоді загострення, які надійшли на стаціонарне лікування у дитячу лікарню м. Києва.

Всім дітям було проведено ФЕГДС з прицільною біопсією СО тіла, антрального відділу шлунка для подальшого морфологічного та імуногістохімічного дослідження. При морфологічному дослідженні СО фундального і антрального відділів шлунка у $67,9 \pm 4,4 \%$ пацієнтів діагностували еозинофільний гастрит, у $32,1 \pm 4,4 \%$ - лімфоцитарний гастрит. При лімфоцитарному гастриті у фундальному і антральному відділах шлунка були відмічені порушення рельєфу СО у вигляді вкорочення ямок і сплощення валиків, явища периваскулярного набряку. Власна пластинка СО 
інфільтрована лімфоцитами до 25 в полі зору і поодинокими плазмоцитами, еозинофілами та нейтрофілами, які локалізуються, в основному, у поверхневих відділах $\mathrm{CO}$ і у валиках. Відмічали вогнища гіпотрофії СО зі зменшенням кількості залоз, архітектоніка їх була порушена (рис.1).

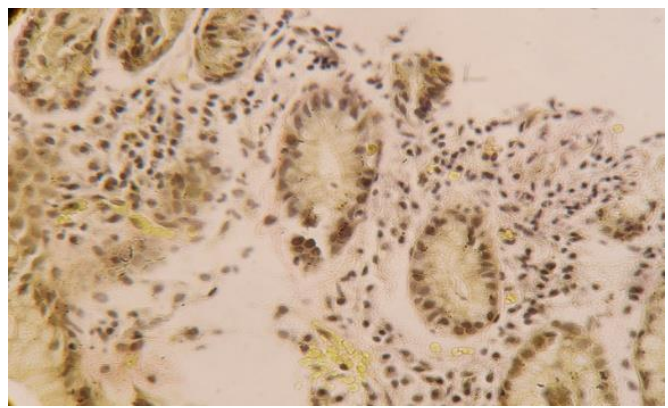

Рис.1. Мікрофото біоптата СОШ. Лімфоцитарний гастрит Х 200.

При еозинофільному гастриті в фундальному і антральному відділах шлунка рельєф СО був порушений, відмічали вкорочення ямок і сплощення валиків у всіх спостереженнях. Поверхневий епітелій з ділянками десквамації і вогнищами сплощення. Власна пластинка СО інфільтрована лімфоцитами до 10 в п/зору і еозинофілами до 25-30 в п/зору, вогнища периваскулярного набряку, ерозії, крововиливи, мікротромбози у всіх біоптатах. У власній пластинці СОШ відмічали вогнища фіброзу різних розмірів від 50-70 мкм до 100-150 мкм, проліферації фібробластів і тонких колагенових волокон у більшості біоптатів, які мають нечіткі контури і перебувають як у базальних, так і поверхневих відділах. Залози у власній пластинці розташовуються нерівномірно, 3 вогнищами деструкція. В антральному відділі шлунка визначали вогнища ерозій (рис.2)

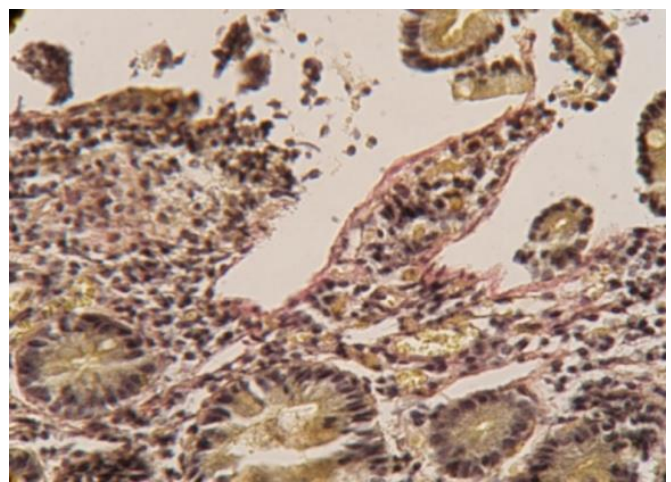

Рис.2. Мікрофото біоптата СОШ. Еозинофільний гастрит. Х200.

Імунногістохімічні показники клітинного гомеостазу при еозинофільному гастриті характеризувалися збільшенням проліферативної активності: експресії PCNA становила від 10,6\% до 42,1\% позитивно пофарбованих ядер епітелію залоз, експресія Вах - від 10,3 до 29,1\% позитивно пофарбованих клітин і експресія Bcl-2 - менше 10\% позитивно пофарбованих клітин (рис.3).

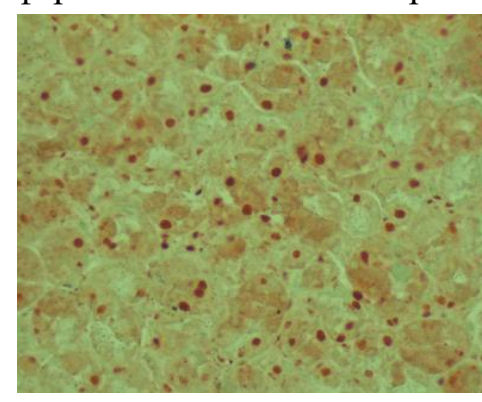

a

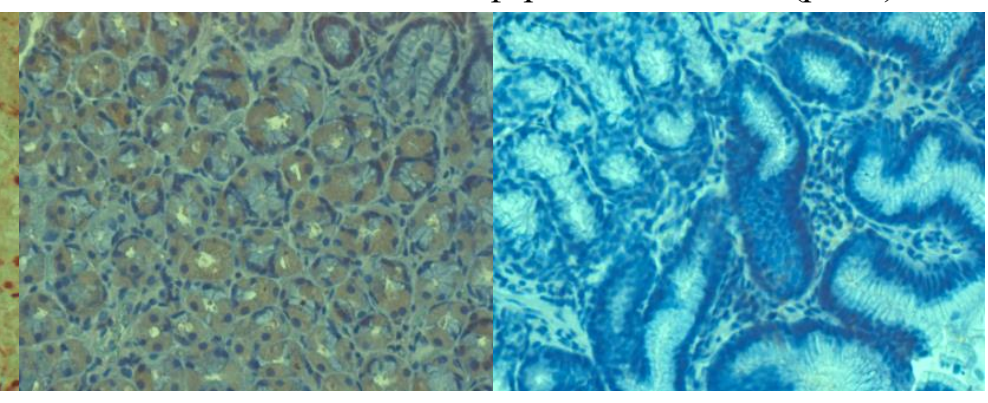

б

B

Рис.3. Мікрофото біоптата СОШ. Еозинофільний гастрит: а-імуногістохімічна реакція з антитілами до РCNA. Х 200; б-імуногістохімічна реакиія з антитілами до Вах. Х 200; вімуногістохімічна реакція з антитілами до Bcl- 2. Х 200. 
При проведенні аналізу рівня показників клітинного відновлення у пацієнтів при лімфоцитарному гастриті нами була відмічена тенденція до зростання проапоптозного показника Вах від 82,4\% до 96,1\% позитивно пофарбованих клітин при низькій експресії $\mathrm{Bcl}-$ 2 (менше 10\% позитивно пофарбованих клітин) і низькій експресії PCNA від 0,9\%-2\% позитивно пофарбованих клітин (рис. 4.).

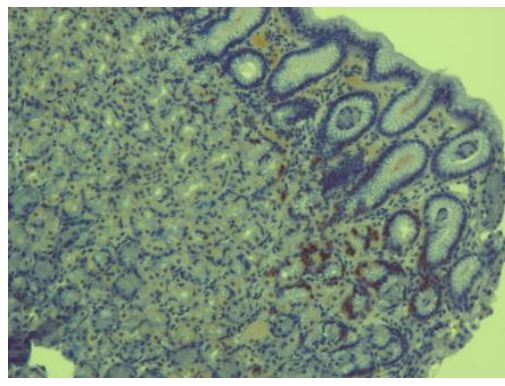

$a$

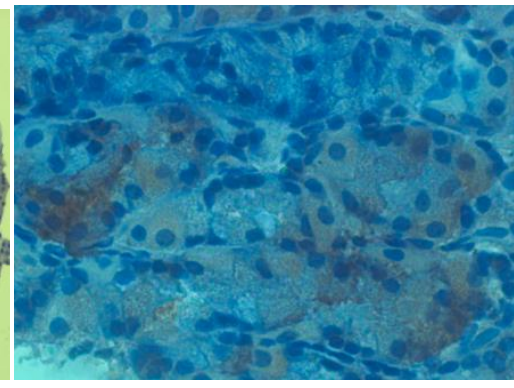

б

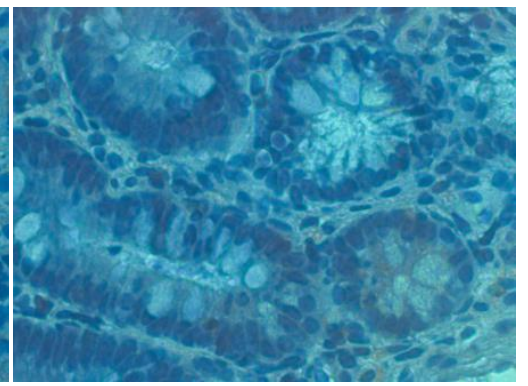

B

Рис.4. Мікрофото біоптата СОШ. Хронічний атрофічний гастрит: $a$-імуногістохімічна реакиія з антитілами до РСNA. Х 100; б -імуногістохімічна реакиія з антитілами до Вах.

X 200; в-імуногістохімічна реакиія з антитілами до $\mathrm{Bcl}-2$. X 200.

Зважаючи на отримані нами результати морфологічного дослідження, щодо порушень мікроциркуляції СОШ при еозинофільному гастриті, нами було проведено дослідження васкулярно - ендотеліальний фактор росту VEGFR1, який відіграє важливу роль у відтворенні судинної капілярної сітки та відновленні мікроциркуляції в СОШ. При імуногістохімічному дослідженні біоптатів шлунка ми виявили нерівномірну експресію рецептора VEGFR1 в ендотеліальних клітинах шлунка. У $57,9 \pm 5,7 \%$ пацієнтів при еозинофільному гастриті розповсюдженість реакції імунозабарвлення до VEGFR1 становила більше $10 \%$ і менше $50 \%$ позитивно забарвлених клітин (рис.5а). У 47,2 $28,3 \%$ пацієнтів з лімфоцитарним гастритом розповсюдженість реакції VEGFR1 була менше 10\% позитивно забарвлених клітин (рис.5 б)

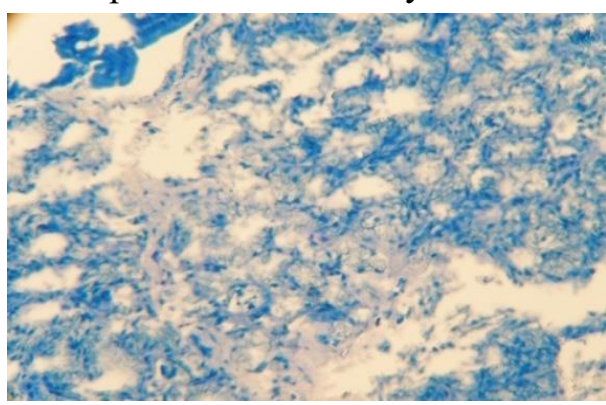

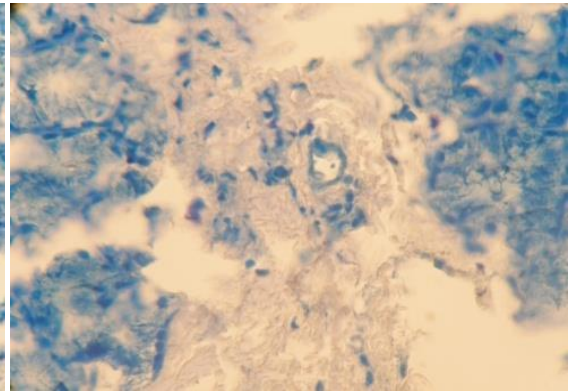

6

Pис.5. Мікрофото біоптата СОШ. Непрямий стрептавидін-пероксидазний метод забарвлення. Експресія з моноклональними антитілами до рецептора VEGFR1 X 200. $a$ - еозинофільний гастрит; б - лімфоцитарний гастрит

Отримані дані у пацієнтів при еозинофільному гастриті щодо проявів проліферації фібринових і колагенових волокон у власній пластинці СОШ як показників стромальноепітеліальної перебудови CO, вказали на необхідність дослідження колагену IV типу, який характеризує трофічну функцію власної пластинки СО і якість регенераторних процесів. Експресія рецепторів до колагену IV типу була виявлена у вигляді окремих фрагментованих вогнищ в базальних мембранах поверхневого епітелію і поодиноких залозистих структурах. При еозинофільному гастриті розповсюдженість реакції з використанням моноклональних антитіл до Collagen Typ IV у більшості дітей $(56,6 \pm 5,7 \%)$ була менше $10 \%$ позитивно забарвлених клітин (рис.6 а), при лімфоцитарному гастриті - більше 10\% і менше 50\% позитивно забарвлених клітин (рис.6 б) 


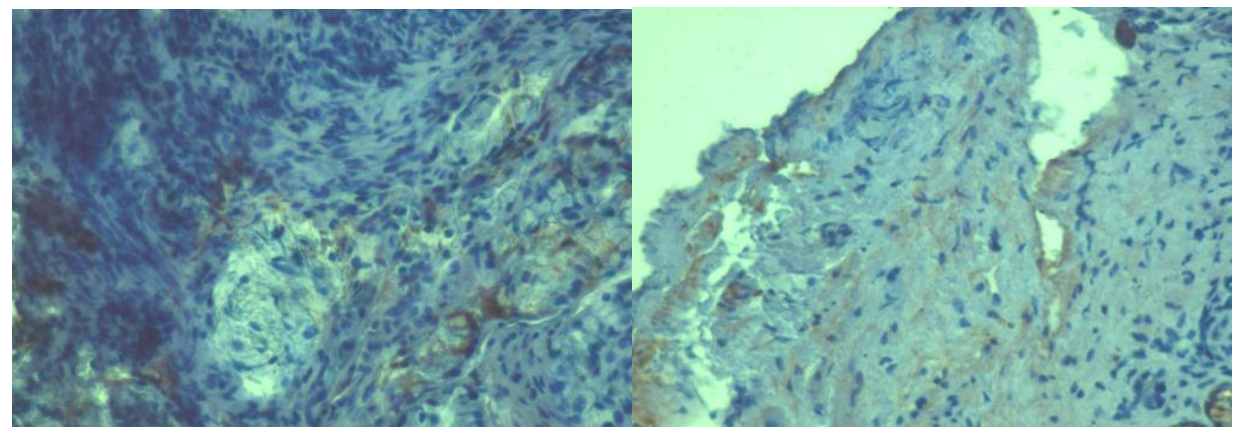

$a$

$\sigma$

Рис.6. Мікрофото біоптата СОШ. Експресія з моноклональними антитілами до колагену

IV типу. X 200. а - еозинофільний гастрит; б - лімфоцитарний гастрит.

Вище викладене вказує на актуальність вивчення трансформуючого фактору росту (TGF $\beta$ ), який бере участь в регуляції процесів відновлення епітеліальних структур, сполучної тканини, а також судин і м'язового шару. Експресія рецепторів до TGF $\beta$ в цитоплазмі і ядрах епітеліоцитів була нерівномірна. Виражене імунозабарвлення TGFR $\beta$, більше $50 \%$ позитивних клітинних елементів, виявили у 40,8 $\pm 5,6 \%$ хворих при еозинофільному гастриті з вираженим фіброзом та проліферацією (рис.7 а). При лімфоцитарному гастриті розповсюдженість реакції 3 TGF $\beta$ визначалася лише $11,1 \pm 5,2 \%$ пацієнтів і вона становила менше $10 \%$ позитивно забарвлених клітин при слабкому забарвлені реакції (рис.7 б)

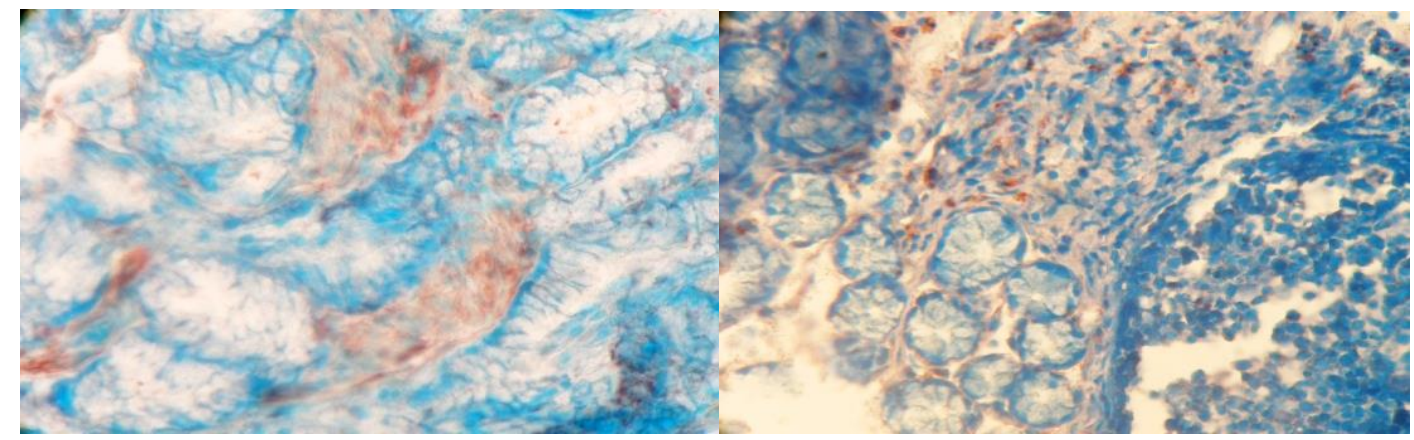

Рис.7. Мікрофото біоптату СОШ. Експресія з поліклональними антитілами до TGFß. Х 200. a - еозинофільний гастрит; б - лімфочитарний гастрит.

Висновки. На підставі проведеного дослідження встановлені морфологічні зміни СО, які $\epsilon$ патогномонічними для еозинофільного гастриту i проявляються еозинофільною інфільтрацією, фіброзом строми власної пластинки, мікроциркуляторними порушеннями 3 явища множинних крововиливів, тромбозів, ерозій. На нашу думку, мікроциркуляторні порушення СОШ пов'язані саме 3 еозинофільною інфільтрацією власної пластинки СО. Еозинофіли, як відомо, містять високі концентрації пероксидази, яка підвищує судинну проникливість і призводить до розвитку васкуліту.

При імуногістохімічному дослідженні біоптатів СО шлунку були виявлені особливості розповсюдженості та інтенсивності реакції імунозабарвлення до VEGFR 1, показник якого був вищим у пацієнтів з еозинофільним гастритом. Так як VEGFR $1 \in$ головним індуктором ангіогенезу, забезпечує відновлення сполучної тканини і мікросудин, тому підвищення рівня експресії рецептора, ймовірно, пояснює раніш отримані нами дані стосовно гемоциркуляторних розладів СОШ саме серед пацієнтів з еозинофільним гастритом.

Розповсюдженість і інтенсивність реакції імунозабарвлення до Collagen Typ IV, як показника стромально-судинного компоненту травного каналу, у пацієнтів при еозинофільному гастриті була слабкою у вигляді окремих фрагментованих вогнищ в базальних мембранах поверхневого епітелію і поодиноких залозистих структурах. Отримані дані, на наш погляд свідчать про те, що при еозинофільному гастриті $є$ порушення трофічної функції власної пластинки СО і зниження регенераторних процесів в СОШ.

При еозинофільному гастриті у дітей були виявлені структурні особливості дисрегенерації, які проявляються дисбалансом процесів клітинного відновлення Виражене 
підвищення індексу проліферації епітеліоцитів шлунка при еозинофільному гастриті вказує на можливість порушення фізіологічної регенерації СО. При підвищенні індексу проліферації епітеліоцитів відбувається збільшення не диференційованих клітин, що не спроможні виконувати притаману їм функцію і це призводить до розвитку стромально-епітеліальної перебудови СОШ.

При інтерпретації реакції імунозабарвлення з використанням поліклональних антитіл до TGF $\beta$, встановлено, що при еозинофільному гастриті у більшості пацієнтів розповсюдженість та інтенсивність реакції була вираженою. Нами встановлено, що високий рівень розповсюдженості позитивно забарвлених клітин відмічали саме при фіброзі та проліферації фібробластів, колагенових волокон у базальних і поверхневих відділах власної пластинки СО.

Таким чином, виявлені нами характерні морфологічні та імуногістохімічні зміни СОШ при еозинофільному гастриті, а саме структурні особливості дисрегенерації, дисбаланс процесів клітинного відновлення, мікроциркуляторні порушення і стромально-епітеліальна перебудова СОШ свідчать про формування фіброзного ремоделювання при еозинофільному гастриті у дітей.

\section{ЛІТЕРАТУРА}

1. Aceves SS, Newbury RO, Chen D, Mueller J, Dohil R, Hoffman H, Bastian JF, Broide DH. Resolution of remodeling in eosinophilic esophagitis correlates with epithelial response to topical corticosteroids. Allergy. 2010;65(1):109-16.

2. Collins MH. Histopathology associated with eosinophilic gastrointestinal diseases. Immunol Allergy Clin North Am. 2009;29 (1):109-17, https://doi.org/10.1016/j.iac.2008.10.005.

3. Guidelines for the Diagnosis and Management of Food Allergy in the United States: Report of the NIAIDSponsored Expert Panel // J. Allergy Clin.Immunol. 2010.Vol. 126, № 6. P.1-58. doi:10.1016/j.jaci.2010.10.007

4. Jensen ET, Martin CF, Kappelman MD, Dellon ES. Prevalence of eosinophilic gastritis, gastroenteritis, and colitis: Estimates from a National Administrative Database. J Pediatr Gastroenterol Nutr. 2016;62(1):3642. https://doi.org/10.1097/MPG.0000000000000865.

5. Jawairia M, Shahzad G, Mustacchia P. Eosinophilic gastrointestinal diseases: review and update. ISRN Gastroenterol. 2012;2012:463689. https://doi.org/10.5402/2012/463689

6. Lucendo AJ, Arias A, De Rezende LC, Yague-Compadre JL, Mota-Huertas T, Gonzalez-Castillo S, Cuesta RA, Tenias JM, Bellon T. Subepithelial collagen deposition, profibrogenic cytokine gene expression, and changes after prolonged fluticasone propionate treatment in adult eosinophilic esophagitis: a prospective study. J Allergy Clin Immunol. 2011;128(5):1037-46. https://doi.org/10.1016/j.jaci.2011.08.007.

7. Lemale J, Dainese L, Tounian P. Eosinophilic gastroenteritis and colitis in pediatric patients: Increasingly frequent diseases. Arch Pediatr. 2015;22(7):769-77. https://doi.org/10.1016/j.arcped.2015.04.005.I

8. Naramore S, Gupta SK. Nonesophageal eosinophilic gastrointestinal disorders: clinical care and future directions. J Pediatr Gastroenterol Nutr. 2018;67(3):318-21. https://doi.org/10.1097/MPG.0000000000002040.

9. Rothenberg ME. Eosinophilic gastrointestinal disorders (EGID). J Allergy Clin Immunol. 2004;113(1 ):1128. https://doi.org/10.1016/j.jaci.2003.10.047.

10. Straumann A, Conus S, Degen L, Felder S, Kummer M, Engel H, Bussmann C, Beglinger C, Schoepfer A, Simon HU. Budesonide is effective in adolescent and adult patients with active eosinophilic esophagitis. Gastroenterology. 2010;139(5):1526-37, 1537.e1. https://doi.org/10.1053/j.gastro.2010.07.048.

11. Straumann A, Conus S, Degen L, Frei C, Bussmann C, Beglinger C, Schoepfer A, Simon HU. Long-term budesonide maintenance treatment is partially effective for patients with eosinophilic esophagitis. Clin Gastroenterol Hepatol. 2011;9(5):400-9.e1. https://doi.org/10.1016/j.cgh.2011.01.017.

12. Uppal V., Kreiger P., Kutsch E. Eosinophilic Gastroenteritis and Colitis: a Comprehensive Review. // Clin. Rev. Allergy Immunol. 2016.Vol.50, № 2. P. 175-188 (ISSN: 1559-0267)

13. Valent P, Klion AD, Rosenwasser LJ, Arock M, Bochner BS, Butterfield JH, Gotlib J, Haferlach T, Hellmann A, Horny HP, Leiferman KM, Metzgeroth G, Matsumoto K, Reiter A, Roufosse F, Rothenberg ME, Simon HU, Sotlar K, Vandenberghe P, Weller PF, Gleich GJ. ICON: eosinophil disorders. World Allergy Organ J. 2012;5(12):174-81. https://doi.org/10.1097/WOX.0b013e31827f4192.

14. Ziegler SF. The role of thymic stromal lymphopoietin (TSLP) in allergic disorders. Curr Opin Immunol. 2010; 22(6):795-9. https://doi.org/10.1016/j.coi.2010.10.020 